\title{
Allelopathic effects of Calliandra calothyrsus Meisn, Senna siamea $L$. and Gliricidia sepium (Jacq.) Walp Leaves on Maize (Zea mays L.) and Bean (Phaseolus vulgaris L.) Root and Shoot Growth
}

\section{KABONEKA Salvator*1 ${ }^{1}$, NSAVYIMANA Gaston ${ }^{2}$, NKURUNZIZA Menus ${ }^{3}$ and NTEZUKWIGIRA Godefroid $^{1}$}

\author{
${ }^{1}$ Faculty of Agriculture and Bio-Engineering, Department of Environment Sciences and \\ Technologies.University of Burundi. P.O. Box 2940 Bujumbura, Burundi
}

${ }^{2}$ Faculty of Sciences, Department of Chemistry. University of Burundi. P.O. Box 2700 Bujumbura, Burundi.

${ }^{3}$ Faculty of Sciences, Department of Mathematics. University of Burundi. P.O. Box 2700 Bujumbura, Burund

\begin{abstract}
With the promotion of so-called multipurpose agroforestry species in Burundi, Calliandra calothyrsus Meisn, Senna siamea L. and Gliricidia sepium (Jacq.)Walp have been the three widely disseminated leguminous shrubs to farmers for use as climbing bean stakes, fuelwood, fodder and green manure. However, of recent, field reports indicate that direct application of their foliar biomass as green manure show some negative effects on plant growth. For that matter, laboratory and greenhouse studies were set up to examine and compare the susceptibility of maize (Zea mays L.) and bean (Phaseolus vulgaris L.) to allelopathic effects of Calliandra calothyrsus Meisn, Senna siamea and Gliricidia sepium (Jacq.) Walp. Data were collected on seed germination, radicle elongation, root and shoot growth, root, shoot and total dry biomass. The study revealed tangible depressive effects of leaves of all three tested leguminous species, particularly on radicle elongation, root and shoot growth of tested crop species. The inhibitory effects were more pronounced at higher application rates on bean than on maize growth, while roots were more sensitive than shoots. This is an indication that allelochemicals are not only species specific, but also organ specific as well as concentration dependent. Overall, the allelopathic effect followed the order: Gliricidia sepium > Senna siamea = Calliandra calothyrsus. The study outlined the potential detrimental effect of agroforestry species foliar biomass on associated plant growth when directly applied to the soil. As an alternative, we recommend to farmers the co-composting approach with low quality crop harvest residues (e.g. maize stover, wheat straw), in which the leguminous leaves play a stimulatory effect on the overall decomposition, allelochemicals dissipation and plant nutrient release.
\end{abstract}

Key Words: Allelopathy, Agroforestry species, Bean, Maize, Root, Shoot.

\section{INTRODUCTION}

A number of agroforestry species has been introduced in Burundi through research supported by the International Center for Research in Agroforestry during the 1980's. Three of the most studied and promoted species were Calliandra calothyrsus Meisn, Senna siamea L. and Gliricidia sepium (Jacq.) Walp. One the criteria of agroforestry species selection is their potential allelopathic effect on associated crops. Chemical compounds synthezied and excreted by plants might have physical, chemical and biological effects on another proxy plant and sourrounding vegetation[1-8]. Such process has been termed «allelopathy » or phytotoxicity. The most accepted and refered definition of this biochemical process is Rice's (2012)[9] who defines allelopathy as « the ability of plants to inhibit the germination of other plants through the production of allelochemicals which may be present in any parts of the plants, i.e, leaves, roots, flowers, fruits, stems, rhizomes, buds and seeds, from where they are released to the soil through volatilization, root exudation, leaching and decomposition of plant residues and could affect either positively or negatively germination and growth of other species or even within the same species ». The action of the allelochemical compounds may be stimulatory, neutral, or inhibitory depending on their concentration and/or sensitivity of the receiving target

www.ijasre.net 
plant or plant organ[10-15]. As such, it is obvious that this physiological phenomenon requires special attention when introducing agroforestry species in tree-crop association.

Physiological processes affected by allelochemicals are wide and varied [9, 16]: cell division; change in hormonal synthesis, equilibrium and regulation; biosynthis of cellular constituents; enzymatic activity; plant-water relationships; photosynthesis and respiration; plasma membrane permeability of the roots; pollen tube germination; protein synthesis; root elongation; rate of ion absorpltion by plants; pigment and changes in DNA and RNA structure; mitotis; reduction of flower and fruit formation, inhibition or stimulation of stomatal opening and conductance; changes in lipids and organic acid metabolism.

Over the years, appreciable knowledge has been accumulated and different classes of allelochemicals have been identified in the species Calliandra calothyrsus Meisn, Senna siamea L. and Gliricidia sepium (Jacq.). Phytochemical studies carried out on those three species have shown the presence of tannins, flavonoids, terpenoids, alkaloids, steroids, phenolic compounds, anthraquinones, leucoanthocyanin, saponins and flavonol glycosides[17-35]. However, the abundance detected for the different allelochemical molecules was variable according to these authors. Hypothetically, given the variable abundance of these allelochemical compounds in these three agroforestry species, our study considers that other crops associated are differently affected. It is known that auxin, gibberellin and cytokinins are biochemical substances that intervene in different plant growth phases[36]. They are active in cellular differentiation, multiplication and growth, in other words in organogenesis[37]. Antagonistic substances [e.g. abscissic acid, trans-sinapinic acid, coumaric acid(p-coumaric acid, m-coumaric acid, o-coumaric acid)] to these growth hormons are inhibitors of seed germination, root growth and elongation, enzyme activity and photosynthesis[15, 37-39].

In view of the chemical structures of these allelochemicals, some of them being shown in Figures 1-3 as illustration and others in the study carried out by Kumar et al. (2017)[33], it is deductible that their biological activity on the growth of crops associated with the agroforestry species that generate them varies according to many variables: the amount of the allelochemicals concerned, growth phase of the plant, and other associated parameters.Although allelopathicphenomenons are observed in the field, greenhouse and laboratory experiments with residues, extracts or purified allelochemicals, we must recognize real difficulties to separate allelopathy from water and nutrient competition and other field interferences[9, 39, 40]. To be effective, allelopathic effects must be evaluated from the early plant development stages i.e seed germination, growth on cotyledonary reserves, because afterwards inhibitive effects dissipate through volatilization, leaching and decomposition[9, 41].

This study specifically examines the susceptibility of maize (Zea mays L.) and beans (Phaseolus vulgarisL.) to allelopathic effects of CalliandracallothyrsusMeisn, Sennasiamea L. and Gliricidiasepium (Jacq.) Walpunderlaboratory and greenhouse conditions.

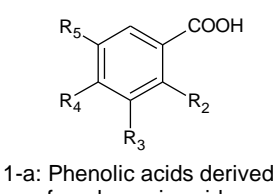

from benzoic acids

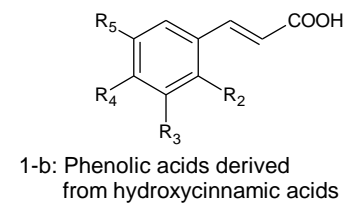

from hydroxycinnamic acids<smiles>[R]c1ccc(/C=C/C(=O)O)c([R])c1[R]</smiles>

2: Coumaric acids

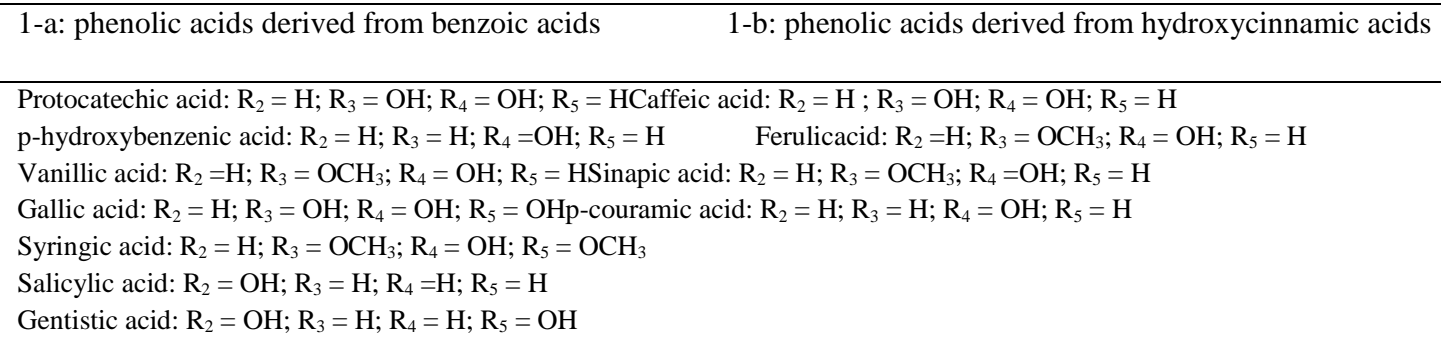

Figure 1: Chemical structures of phenolic acids (1-a \& 1-b) and coumaric acids (2) (Source: [33, 42]). 
<smiles>c1ccc(C2CCc3ccccc3O2)cc1</smiles>

3-a<smiles>O=c1cc(-c2ccc(O)cc2)oc2cc(O)cc(O)c12</smiles>

$3-b$<smiles>O=c1c(O)c(-c2ccc(O)cc2)oc2cc(O)cc(O)c12</smiles>
$3-c$<smiles>O=c1cc(-c2ccc(O)c(O)c2)oc2cc(O)cc(O)c12</smiles>

3-d<smiles>O=c1cc(-c2ccc(O)c(O)c2O)oc2cc(O)c(O)cc12</smiles>

3-a: Basic structure of flavonoids /2-phenyl-3,4-dihydro-2H-chromene

3-b: 5,7-dihydroxy-2-(4-hydroxyphenyl)-4H-chromen-4-one

3-c: 3,5,7-trihydroxy-2-(4-hydroxyphenyl)-4H-chromen-4-one

3-d: 2-(3,4-dihydroxyphenyl)-5,7-dihydroxy-4H-chromen-4-one

3-e: 6,7-dihydroxy-2-(2,3,4-trihydroxyphenyl)-4H-chromen-4-one

Figure 2: Chemical structures of flavonoids (Source: [33]).<smiles>Cc1cc(O)c2c(c1)C(=O)c1cc(O)c(-c3c(C)cc4c(c3O)C(=O)c3c(O)cc(O)cc3C4=O)c(O)c1C2=O</smiles><smiles>COc1cc(OC)c2c(c1)C(=O)c1c(O)c(C)c(O)c(-c3c(O)c(C)c(O)c4c3C(=O)c3c(OC)cc(OC)cc3C4=O)c1C2=O</smiles>

4-a: 2-(1,8-dihydroxy-3-methyl-9,10-dioxoanthracen-2-yl)-1,6,8-trihydroxy-3-methylanthracene-9,10-dione /also called Cassiamin A.

4-b: 1,3,8-trihydroxy-6-methyl-2-(1,6,8-trihydroxy-3-methyl-9,10-dioxoanthracen-2-yl) anthracene-9,10-dione/also called madagascarin

4-c: 4,4'-Bis (1,3-dihydroxy)-2-methyl-6,8-dimethoxyanthraquinone)

Figure 3: Chemical structures of anthraquinones(Source: [33]). 


\section{MATERIALS AND METHODS}

Our research was conducted under controlled conditions. Germination tests were conducted in petri dishes and in pots under greenhouse conditions for growth parameters: root and shoot growth (height), root, shoot and total dry biomass.

\subsection{Tested species}

Both laboratory and greenhouse studies used three of the most adopted agroforestry species in Burundi: Calliandra calothyrsusMeisn, Senna siamea L. and Gliricidia sepium (Jacq.) Walp.

Calliandra calothyrsus Meisn is a leguminous species originating from South America. The species has been introduced in Burundi for its high N-fixing potential, abundant biomass production and rapid decomposition[43]. Calliandra calothyrsus Meisn can produce as much as $18.4 \mathrm{~T} / \mathrm{ha} /$ year for the first, $3.4 \mathrm{~T} / \mathrm{ha} /$ year for the second and $3.8 \mathrm{~T} / \mathrm{ha} / \mathrm{year}$ for the third cutting[44, 45].

Originated from South-East Asia, Senna siamea L. is currently largely distributed all over tropical regions. Its total biomass production can attain $10 \mathrm{~T} / \mathrm{ha} /$ year of which $70 \%$ are foliar biomass[45]. The species is adapted to low altitude zone in Burundi.

Gliricidia sepium (Jacq.) Walp originates from Central America. Like Senna siamea L., the species is also most adapted to low altitude zone in Burundi. Its total fresh biomass production is ranging between 2 and $12 \mathrm{~T} / \mathrm{ha} / \mathrm{year}$ with a production per $\mathrm{m}^{2}$ of about $8 \mathrm{~kg} / \mathrm{m}^{2}$, and of which 30 to $60 \%$ is constituted by foliar biomass, depending on climatic and soil conditions[44].

Crop species tested were maize (Zea mays L.) and beans (Phaseolus vulgaris L.). The two crops have been selected because of their importance in food security and nutrition in Burundi. Maize and bean seeds were obtained from the Burundi Agriculture Research Institute. Fresh samples of Calliandra calothyrsus Meisn, Senna siamea L. and Gliricidia sepium (Jacq.) Walp were collected from trees located nearby the same Research Institution.

\subsection{Soil used}

The 20-cm depth soil used in the greenhouse experiment was collected from the Faculty of Agronomy and Bio-Engineering of the University of Burundi. The soil was air-dried, crashed and sieved through a 2 -mm sieve. Performed soil chemical analyses included $\mathrm{pH}, \% \mathrm{C}, \% \mathrm{~N}$, cation exchange capacity (CEC), exchangeable $\mathrm{Ca}^{2+}, \mathrm{Mg}^{2+}$, and $\mathrm{K}^{+}$. Soil $\mathrm{pH}$ was measured using a $1: 1$ soil-water mixture. Organic $\mathrm{C}$ was determined using the Walkely-Black wet oxidation method [46]. Organic N was measured as described by Bremner and Mulvaney[47]. Cation exchange capacity (CEC) was determined by the $1 \mathrm{M}$ ammonium acetate saturation method $(\mathrm{pH}=7.0)$ [48]. Exhangeablecations were determined by ICP spectrophotometry after extraction by the Mehlich III method [49]. Selected chemical caracteristicsare shown in Table 2.

\subsection{Experimental Design and tested treatments}

Both laboratory and greenhouse investigations were run in a Completely Randomized Design (CRD) and replicated thrice with 7 treatments described in Table 1.

Table 1. Characteristics of different tested treatments.

\begin{tabular}{cll}
\hline Treatment & Petri dish assay & Pot study \\
\hline $\mathrm{T}_{1}$ & Control (distilled water) & Control (distilled water) \\
$\mathrm{T}_{2}$ & $2 \mathrm{~g}$ de C. caloth. $/ 100 \mathrm{ml}$ of $\mathrm{H}_{2} \mathrm{O}$ & $2 \mathrm{~g}$ of C. calothyrsus $/ 4 \mathrm{~kg}$ of soil \\
$\mathrm{T}_{3}$ & $4 \mathrm{~g}$ de C. caloth. $/ 100 \mathrm{ml}$ of $\mathrm{H}_{2} \mathrm{O}$ & $4 \mathrm{~g}$ of C. calothyrsus $/ 4 \mathrm{~kg}$ of soil \\
$\mathrm{T}_{4}$ & $2 \mathrm{~g} \mathrm{de} \mathrm{S}$. siamea $/ 100 \mathrm{ml}$ of $\mathrm{H}_{2} \mathrm{O}$ & $2 \mathrm{~g}$ of S. siamea $/ 4 \mathrm{~kg}$ of soil \\
$\mathrm{T}_{5}$ & $4 \mathrm{~g} \mathrm{de} \mathrm{S.} \mathrm{siamea} / 100 \mathrm{ml}$ of $\mathrm{H}_{2} \mathrm{O}$ & $4 \mathrm{~g}$ of S. siamea $/ 4 \mathrm{~kg}$ of soil \\
$\mathrm{T}_{6}$ & $2 \mathrm{~g}$ de G. sepium $/ 100 \mathrm{ml}$ of $\mathrm{H}_{2} \mathrm{O}$ & $2 \mathrm{~g}$ of G. sepium $/ 4 \mathrm{~kg}$ of soil \\
$\mathrm{T}_{7}$ & $4 \mathrm{~g}$ de G. sepium $/ 100 \mathrm{ml}$ of $\mathrm{H}_{2} \mathrm{O}$ & $4 \mathrm{~g}$ of G. sepium $/ 4 \mathrm{~kg}$ of soil \\
\hline
\end{tabular}




\subsection{Petri dish assay}

The aqueous extracts used in the Petri dish assay were obtained from Calliandra calothyrsus Meisn, Senna siamea L. and Gliricidia sepium (Jacq.) Walp dried leaves at $105^{\circ} \mathrm{C}$ for 24 hours. Dried materials were ground, soaked in volumes specified in Table 1 and filtered using $\mathrm{N}^{\circ} 1$ Whatman filter paper. Ten grains of maize or bean were deposed in each Petri dish on cotton wool saturated with $5 \mathrm{~mL}$ of aqueous extracts corresponding to concentrations indicated above. Seeds were considered germinated upon radicle emergence. Germinated seeds were counted every 24 hours during the 7-day experiment after which radicle elongation was measured. Sufficient moisture in the Petri dishes was maintained by adding aqueous extracts or distilled water as required to wet seeds and not impede their germination. The effects of the extracts were compared with the control treatment in which seeds were saturated with distilled water.

\subsection{Pot study}

Plastic pots were filled with $4 \mathrm{~kg}$ unsterilized top soil. Application rates of tested foliar biomass from Calliandra calothyrsus Meisn, Senna siamea L. and Gliricidia sepium (Jacq.) Walp were 2 and $4 \mathrm{~g} / 4 \mathrm{~kg}$ of soil. Five seeds of each crop were sown per pot and thinned to two plants for maize and three plants for beans three weeks after germination. After germination, pots were moistened every two days to facilitate seedlings establishment. Shoot growth (height) was assessed every 7 days during 35 days. Root length, root biomass and shoot biomass were measured at the end of the 35-day pot study which corresponded to the flowering stage for bean and 7-leave stage for maize. For that, entire maize and bean plants were uprooted and dried. Harvested roots and shoots were dried at $105^{\circ} \mathrm{C}$ for 24 hours to estimate their respective dry weight. Root, shoot, Root/Shoot (R/S) ratios and total biomass per pot were evaluated and compared for treated and control plants.

\subsection{Statistical Analysis}

Statistical analyses were performed using Analysis of Variance (ANOVA) test in Genstat Edition 4. They were conducted on the data were collected on the following growth parameters: seed germination percentage, radicle elongation, root and shoot growth (height), root, shoot and total dry biomass. This ANOVA test was used to determine significant differences between tested treatments. Treatment means were separated using the Student-Newman-Keuls test at $\mathrm{P}=0.05$ [46]. Figures 1 and 2 (see section 3.3.1 and 3.3.2) were made using the GraphPad Prism Software (version 5).

For the germination percent variable, data were normalized through angular transformations using the following formula: $Y=2 \arcsin \sqrt{ }(x / n)$, where $x=$ number of bean and maize germinated seeds after 7 days, $n=$ number of sown seeds.

\section{RESULTS AND DISCUSSION}

\subsection{Characteristics of the soil used in the study}

Table 2 below summarizes physical and chemical properties of the soils used in the study.

Table 2. Selected physical and chemical characteristics of the soil used.

\begin{tabular}{lc}
\hline Parameter & Average value \\
\hline $\mathrm{pH}$ & 6.57 \\
$\% \mathrm{C}$ & 1.24 \\
$\% \mathrm{~N}$ & 0.24 \\
$\mathrm{C} / \mathrm{N}$ & 5.17 \\
$\mathrm{CEC}\left(\mathrm{cmol}_{\mathrm{c}} / \mathrm{kg}\right.$ soil $)$ & 11.30 \\
$\mathrm{Ca}^{2+}\left(\mathrm{cmol}_{\mathrm{c}} / \mathrm{kg}\right.$ soil $)$ & 6.60 \\
$\mathrm{Mg}^{2+}\left(\mathrm{cmol}_{\mathrm{c}} / \mathrm{kg}\right.$ soil $)$ & 2.55 \\
$\mathrm{~K}^{+}\left(\mathrm{cmol}_{\mathrm{c}} / \mathrm{kg}\right.$ soil $)$ & 1.31 \\
$\mathrm{Ca}^{2+} / \mathrm{Mg}^{2+}$ & 2.59 \\
$\mathrm{Mg}^{2+} / \mathrm{K}^{+}$ & 1.95 \\
$\left(\mathrm{Ca}^{2+}+\mathrm{Mg}^{2+)} / \mathrm{K}^{+}\right.$ & 6.98 \\
\hline
\end{tabular}


These results indicate that the soil used has a neutral $\mathrm{pH}$, with low organic matter content and adequate cation exchange capacity (CEC) and basic cations content.

\subsection{Germination Petri dish assay}

At the end of the germination test in Petri dishes, statistical analysis did not show any significant differences either on bean or maize germination percentage ( $\mathrm{p}>0.05$ ). On the contrary, the inhibitory effects of Calliandra calothyrsus Meisn, Senna siamea L. and Gliricidia sepium (Jacq.) Walp leaves were clearly visible for the radicle growth, as shown in Table 3.

Table 3. Bean and maize radicle elongation $(\mathrm{cm})$.

\begin{tabular}{|c|c|c|}
\hline Treatment & Bean radicle elongation & Maize radicle elongation \\
\hline $\mathbf{T}_{1}:$ Control & $7.43 b$ & $12.47 \mathrm{a}$ \\
\hline $\mathrm{T}_{2}$ : Calliandra calothyrsus at $2 \mathrm{~g} / 100 \mathrm{~mL}$ of $\mathrm{H}_{2} \mathrm{O}$ & $9.77 \mathrm{a}$ & $10.33 \mathrm{ab}$ \\
\hline $\mathrm{T}_{3}$ : Calliandra calothyrsus at $4 \mathrm{~g} / 100 \mathrm{~mL}$ of $\mathrm{H}_{2} \mathrm{O}$ & $6.40 \mathrm{~b}$ & $6.97 \mathrm{c}$ \\
\hline $\mathrm{T}_{4}$ : Senna siamea at $2 \mathrm{~g} / 100 \mathrm{~mL}$ of $\mathrm{H}_{2} \mathrm{O}$ & $5.27 \mathrm{bc}$ & $11.67 \mathrm{a}$ \\
\hline $\mathrm{T}_{5}$ : Senna siamea at $4 \mathrm{~g} / 100 \mathrm{~mL}$ of $\mathrm{H}_{2} \mathrm{O}$ & $3.27 \mathrm{c}$ & $8.20 \mathrm{bc}$ \\
\hline $\mathrm{T}_{6}:$ Gliricidia sepium at $2 \mathrm{~g} / 100 \mathrm{~mL}$ of $\mathrm{H}_{2} \mathrm{O}$ & $5.30 \mathrm{bc}$ & $2.83 \mathrm{~d}$ \\
\hline $\mathrm{T}_{7}:$ Gliricidia sepium at $4 \mathrm{~g} / 100 \mathrm{~mL}$ of $\mathrm{H}_{2} \mathrm{O}$ & $3.13 \mathrm{c}$ & $2.50 \mathrm{~d}$ \\
\hline General mean & 5.58 & 7.85 \\
\hline F test & $18.78 * * *$ & $20.98 * * *$ \\
\hline Probability & $<0.001$ & $<0.001$ \\
\hline C.V $(\%)$ & 16.1 & 19.3 \\
\hline
\end{tabular}

Mean values with identical letters within the column are not statistically different at $\mathrm{p}<0.05$.

With the exception of Calliandra calothyrsus Meisn at the lower application rate $\left(2 \mathrm{~g} / 100 \mathrm{~mL}\right.$ of $\left.\mathrm{H}_{2} \mathrm{O}\right)$ which showed a stimulatory effect $(+31.5 \%)$. bean radicle elongation was lower in all other treatments as compared to the control. The highest negative (allelopathic) effect was observed with the highest application rates of Senna siamea (- $55 \%$ ) and Gliricidia sepium (-58 $\%)$. Application rates did not show any effect on bean radicle growth for Senna siamea L. and Gliricidia sepium (Jacq.) Walp, while a significant difference was observed between the higher $\left(4 \mathrm{~g} / 100 \mathrm{~mL}\right.$ of $\left.\mathrm{H}_{2} \mathrm{O}\right)$ and the lower $\left(2 \mathrm{~g} / 100 \mathrm{~mL}\right.$ of $\left.\mathrm{H}_{2} \mathrm{O}\right)$ Calliandra calothyrus Meisn leaves application rates.

With regard to maize crop, radicle elongation was lower in all treatments as compared to the control. Gliricidia sepium (Jacq.) Walp extracts depressed more maize root elongation (- $80 \%$ ), independently of the application rate. For Calliandra calothyrsus Meisn and Senna siamea L., an application rate effect was visible, as the higher rate significantly reduced maize radicle elongation comparatively to the lower application rate. Overall, the depressive effect of the root elongation followed the order: Gliricidia sepium $>$ Senna siamea $=$ Calliandra calothyrsus.

\subsection{Pot study}

\subsubsection{Bean}

Results on the bean growth (expressed in height) has shown exponential growth curves (Figure 4). Analysis of variance performed on germination percentage did not show any significant difference between tested treatments, including the control ( $p>0.05)$. On the hand, significant differences between tested differences were observed for bean root biomass, total biomass and the root/shoot $(\mathrm{R} / \mathrm{S})$ ratio (Table 4). 


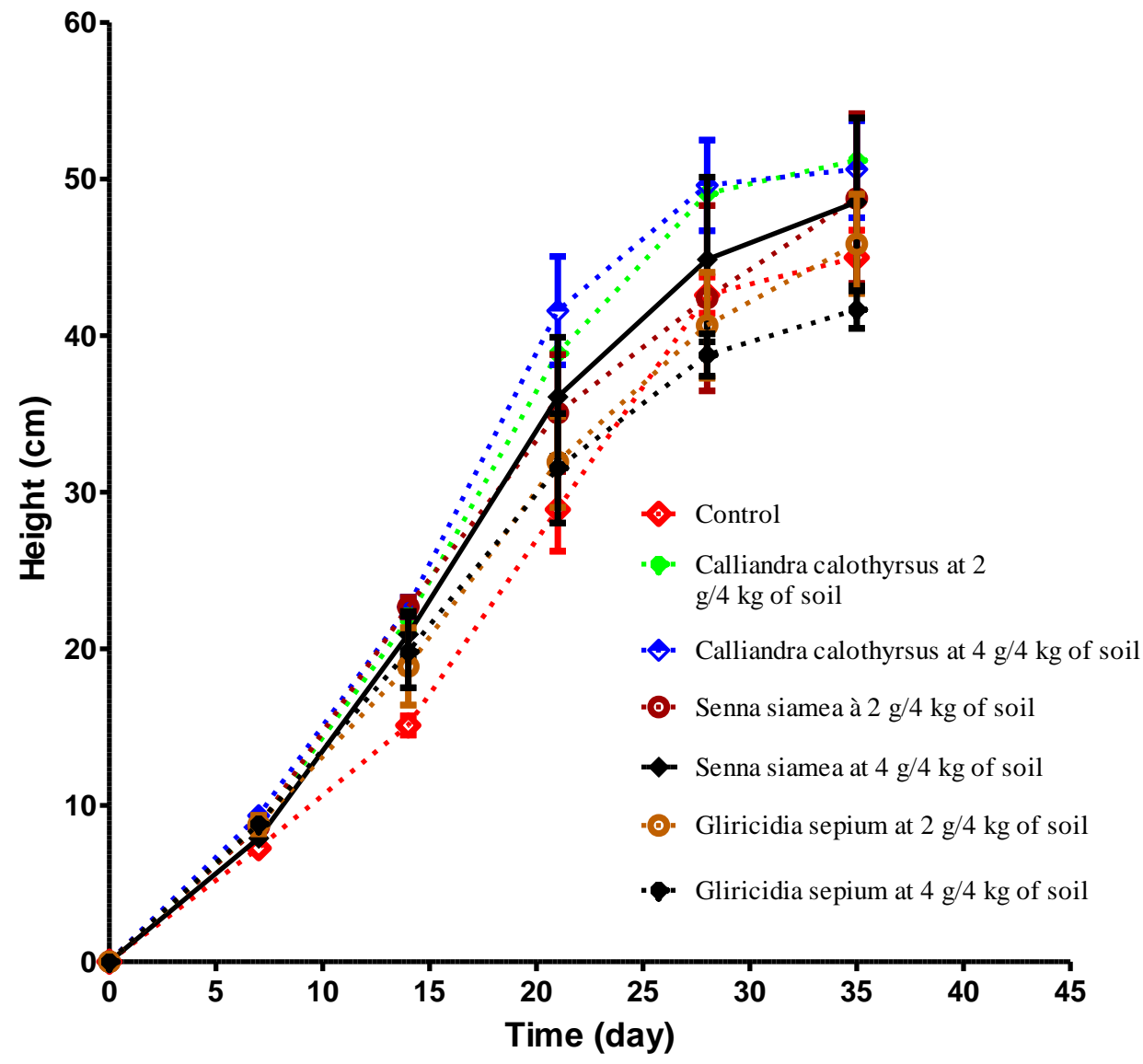

Figure 4.Thirty-five-day bean height growth $(\mathrm{cm})$ in the pot study.

Two-way ANOVA analysis of the exponential bean growth has shown considerable affects of either the treatments $(\mathrm{p}$ value $=$ 0.0001 ) or the time ( $\mathrm{p}$ value $<0.0001$ ).

Figure 4 indicates that, set aside the treatments with Gliricidia sepium (Jacq.) Walp (only from the 25th day), all other treatments showed a slight increase in bean height growth as compared to the control treatment. A simple significant effect of tested treatments was observed on root biomass, shoot biomass and R/S. All amended treatments showed lower root biomass, shoot biomass and R/S comparatively to the unamended/control treatment.

The observed negative effect of selected agroforestry species leaves, both on root biomass, shoot biomass and R/S was more pronounced in soils amended with the higher rates $(4 \mathrm{~g} / 4 \mathrm{~kg}$ of soil) of Senna siamea L. and Gliricidia sepium (Jacq.) Walp. Apparently, Calliandra calothyrsus Meisn at both high and low application rates, and to some extent the lower application rates (2 $\mathrm{g} / 4 \mathrm{~kg}$ of soil) of Senna siamea L. and Gliricidia sepium (Jacq.) Walp showed less inhibitory effects on measured bean growth parameters.

Table 4. Bean root biomass, shoot biomass and root/shoot $(\mathrm{R} / \mathrm{S})$ ratio.

\begin{tabular}{lccc}
\hline Treatment & Root biomass $(\mathrm{g} / \mathrm{pot})$ & Total biomass $(\mathrm{g} / \mathrm{pot})$ & $\mathrm{R} / \mathrm{S}$ \\
\hline $\mathrm{T}_{1}:$ Control & $\mathbf{1 . 1 6 a}$ & $\mathbf{2 . 7 5 a}$ & $\mathbf{0 . 4 1 a}$ \\
$\mathrm{T}_{2}:$ Calliandra calothyrsus at $2 \mathrm{~g} / 4 \mathrm{~kg}$ of soil & $0.88 \mathrm{ab}$ & $2.50 \mathrm{a}$ & $0.35 \mathrm{ab}$ \\
$\mathrm{T}_{3}:$ Calliandra calothyrsus at $4 \mathrm{~g} / 4 \mathrm{~kg}$ of soil & $0.71 \mathrm{ab}$ & $2.37 \mathrm{a}$ & $0.30 \mathrm{ab}$ \\
$\mathrm{T}_{4}:$ Senna siamea at $2 \mathrm{~g} / 4 \mathrm{~kg}$ of soil & $0.92 \mathrm{ab}$ & $2.51 \mathrm{a}$ & $0.35 \mathrm{ab}$ \\
$\mathrm{T}_{5}:$ Senna siamea at $4 \mathrm{~g} / 4 \mathrm{~kg}$ of soil & $0.39 \mathrm{~b}$ & $1.68 \mathrm{a}$ & $0.21 \mathrm{~b}$ \\
$\mathrm{~T}_{6}:$ Gliricidia sepium at $2 \mathrm{~g} / 4 \mathrm{~kg}$ of soil & $0.48 \mathrm{ab}$ & $1.83 \mathrm{a}$ & $0.26 \mathrm{ab}$ \\
$\mathrm{T}_{7}:$ Gliricidia sepium at $4 \mathrm{~g} / 4 \mathrm{~kg}$ of soil & $0.30 \mathrm{~b}$ & $1.48 \mathrm{a}$ & $0.19 \mathrm{~b}$
\end{tabular}


International Journal of Advances in ScientificResearch and Engineering (ijasre), Vol 6 (2), February-2020

$\begin{array}{lccc}\text { General mean } & 0.69 & 2.16 & 0.30 \\ \text { F test } & 4.06 & 3.11^{*} & 4.06^{*} \\ \text { Probability } & <0.05 & <0.05 & <0.05 \\ \text { C.V }(\%) & 39.3 & 22.2 & 23.7\end{array}$

Mean values with identical letters within the column are not statistically different at $\mathrm{p}<0.05$.

\subsubsection{Maize}

Results on the maize growth (expressed in height) hasalso shown exponential growth curves (Figure 5). Analysis of variance (ANOVA) test performed on maize germination percentage, root biomass, shoot biomass, total biomass and Root/Shoot ratio did not detect any significant differences between tested treatments, including the control $(p>0.05)$. Consequently, corresponding data are neither shown nor discussed here. However, significant differences $(p<0.05)$ between treatments were observed for maize height and root length (Table 5 and Figure 5).

Table 5. Root length and height growth $(\mathrm{cm})$ of maize plants.

\begin{tabular}{lcc}
\hline Treatment & Root length & Shoot height \\
\hline $\mathrm{T}_{1}:$ Control & $\mathbf{3 4 . 6 7 a}$ & $\mathbf{5 6 . 8 3 a}$ \\
$\mathrm{T}_{2}:$ Calliandra calothyrsus at $2 \mathrm{~g} / 4 \mathrm{~kg}$ of soil & $38.50 \mathrm{ab}$ & $49.50 \mathrm{ab}$ \\
$\mathrm{T}_{3}:$ Calliandra calothyrsus at $4 \mathrm{~g} / 4 \mathrm{~kg}$ of soil & $42.00 \mathrm{a}$ & $53.00 \mathrm{ab}$ \\
$\mathrm{T}_{4}:$ Senna siamea at $2 \mathrm{~g} / 4 \mathrm{~kg}$ of soil & $30.83 \mathrm{ab}$ & $51.00 \mathrm{ab}$ \\
$\mathrm{T}_{5}:$ Senna siamea at $4 \mathrm{~g} / 4 \mathrm{~kg}$ of soil & $30.83 \mathrm{ab}$ & $44.33 \mathrm{~b}$ \\
$\mathrm{~T}_{6}:$ Gliricidia sepium at $2 \mathrm{~g} / 4 \mathrm{~kg}$ of soil & $40.00 \mathrm{ab}$ & $50.50 \mathrm{~b}$ \\
$\mathrm{~T}_{7}:$ Gliricidia sepium at $4 \mathrm{~g} / 4 \mathrm{~kg}$ of soil & $27.50 \mathrm{~b}$ & $48.67 \mathrm{ab}$ \\
General mean & 34.90 & 50.55 \\
F test & $3.66 *$ & $3.92^{*}$ \\
Probability & $<0.05$ & $<0.05$ \\
C.V $(\%)$ & 14.1 & 6.7 \\
\hline
\end{tabular}




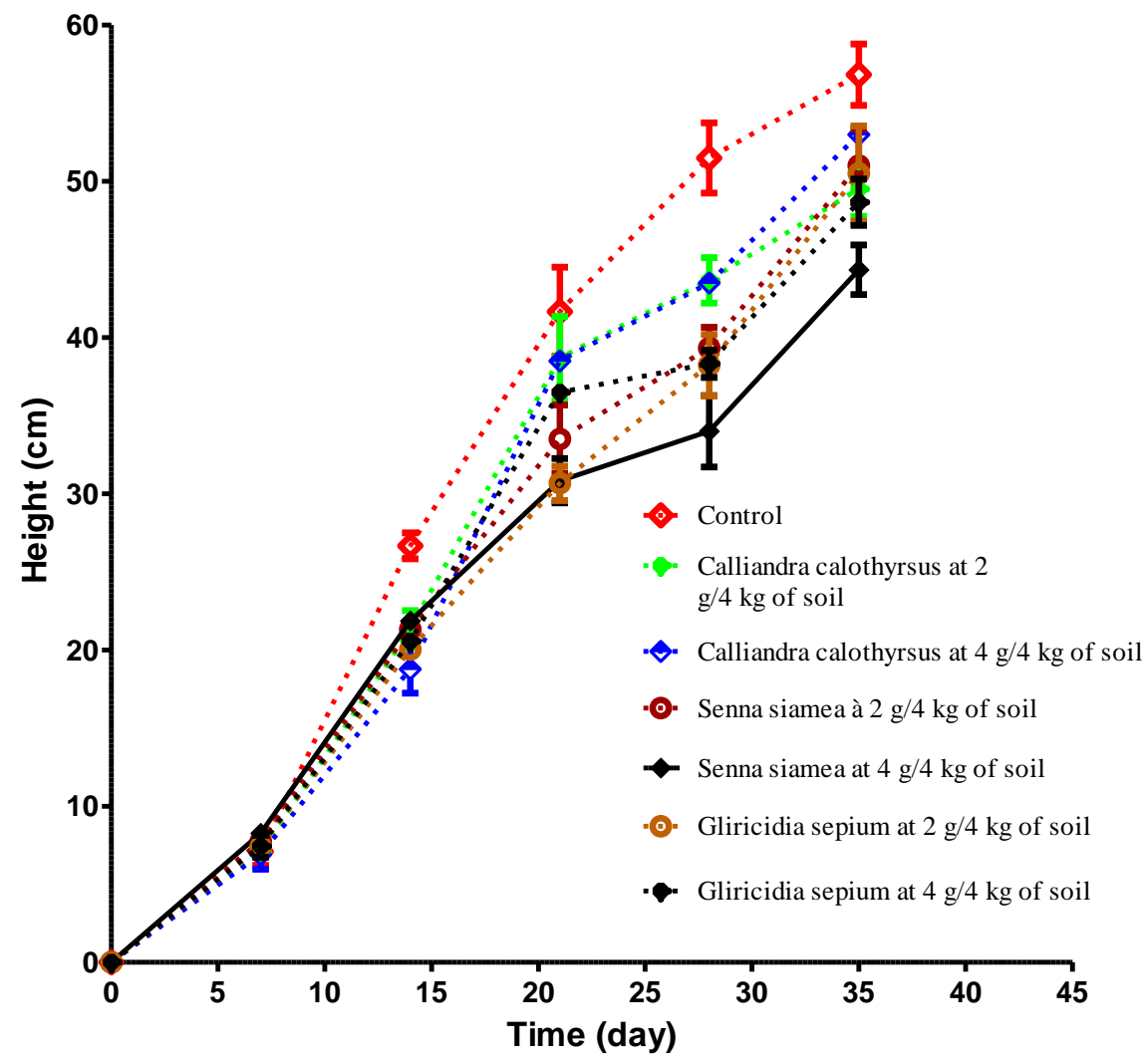

Figure 5.Thirty-five-day maize height growth $(\mathrm{cm})$ in the pot study.

As for the bean growth, the 2-way ANOVA analysis of the exponential maize growth has shown considerable effects of either the treatments $(\mathrm{P}$ value $<0.0001)$ or the time $(\mathrm{P}$ value $<0.0001)$.

Calliandra calothyrsus Meisn at both leaves application rates and Gliricidia sepium (Jacq.) Walp at the lower application rate (2 $\mathrm{g} / 4 \mathrm{~kg}$ of soil) showed some stimulatory effects $(+11$ to $+21 \%)$ on maize root growth as compared to the control treatments. On the other hand, Senna siamea L. at both high and low application rates and Gliricidia sepium (Jacq.)Walp at higher rate (4 g/4 kg of soil) reduced maize root growth, as much as - 11 to - $21 \%$. As for maize height growth, comparatively to the control, a slight reduction $(-14 \%)$ was apparent in most treatments, with the exception of the treatment amended with the higher Sennasiamea L. application rate $(4 \mathrm{~g} / \mathrm{kg}$ of soil), in which as much as $-22 \%$ reduction in maize shoot growth was observed. Again, the inhibitory effect of selected agroforestry species on maize root and shoot growth was as follows: Gliricidia sepium $>$ Senna siamea = Calliandra calothyrsus.

Findings of our investigation are corroborated by other similar works performed under diverse ecological conditions. In fact, many investigators reported allelopathic effects on germination and early growth of a number of staple crops [40, 41, 50-53]. Tian and Kang (1992)[41] reported phytotoxic effects of Gliricidia sepium leachates on maize ((Zea mays L.) and cowpea (Vigna unguiculata L.) seedlings in both laboratory and field conditions[40]. Qudduset al. (2014)[54] and Abugre et al. (2011)[55] observed and reported that plant roots were more sensitive to allelochemicals effects than shoots[53, 55]. A similar conclusion was drawn by Oyun (2006)[40] who observed that seedling root length was the most affected and could, as such, be considered the most suitable and reliable tool for allelopathic studies[40].

Kugedera and Kokerai (2019)[10] reported that Leucaena leucocephala L. contains a toxic, non-protein amino acid (mimosin) that inhibits the growth of other trees[9]. Similar situations were observed with Gliricidia sepium (Jacq.) Walp, whose allelochemicals affect the effectiveness of litter decomposing microorganisms.

Allelochemicals suppress weeds, thus reducing costs of herbicides and weeding. They can be both positive and negative depending on the concentrations[40]. El Ayebet al. (2013)[56] advanced that foliar biomass could be used as post emergence herbicide (biological agriculture), part of the Integrated Pest Management (IPM), while Ayeni (2017)[57] proposed that Senna siamea L. and Pinus carribaea could be used to control weeds[56, 57]. 
When comparing Gliricidia sepium (Jacq.) Walp to Acacia auriculiformis Cunn, Oyun (2006)[40] reported that the former species showed more inhibitory effect on maize ((Zea mays L.) growth[40]. This investigator also found that the inhibition of growth parameters of seedlings was more pronounced than that of seed germination, and, at the same time the inhibition of seed germination and seedling growth were proportional to concentrations of leaf extracts.

From theliterature review, one can notice that contrasting findings on allelopathy were reported by a significant number of investigators[10-15, 39-41, 53]. For example, root extracts of Sennasiamea L. promoted germination of Zea mays L. [53], while leachates of Acacia nilotica (L.) Willd inhibited germination and growth of Zea mays L. and Phaseolus vulgaris L. Aqueous root extracts of Senna siamea L. and Gliricidia sepium (Jacq.) Walp stimulated seed germination of Zea mays L. but inhibited that of Vigna unguiculata L., Hibiscus esculentus L. and Lycopersicum esculentum L. The most dramatic inhibitory effect was observed on Hibiscus esculentus L., while Tithoni adiversifolia (Hemsl.) exhibited stimulatory effects on the vegetative growth of cowpea (Vigna unguiculata L.) and maize Zea mays L.[54]. Interestingly, Mutaquien (2017)[58] reported that gemination of Vigna radiata (L.) R. wilczek was slightly inhibited by allelochemicals released by decomposition processes of Calliandra calothyrsus Meisn leaves. This inhibitory effect was temporary and was progressively reduced over times. Senna siamea L. inhibited the nodulation and $\mathrm{N}$ fixation of clusterbean (Cyanopsis tetragonoloba L.), while Gliricidia sepium (Jacq.)Walp promoted the growth of tomato (Lycopersicum esculentum L.) seedlings[59].

As outlined in the previous discussion and illustrated by our study, allelopathy remains definitely a complex research domain, as the action of allelochemicals may be inhibitory, neutral or stimulatory, even within the same species and presumably under different ecological conditions. Thus, this domain remains an exciting world yet to fully discover and understand.

\section{CONCLUSION}

Because of the difficulties to separate allelopathy from water, nutrient and light field interferences and competition, allelopathic effects are best evaluated from the early plant development stages (radicle elongation, root and shoot growth) under controlled conditions. Such an approach was used in our study to compare the potential inhibitory effects of Calliandra calothyrsus Meisn, Senna siamea L. and Gliridia sepium (Jacq.) Walp leaves on bean (Phaseolus vulgaris L.) and maize (Zea mays L.) early growth under laboratory and greenhouse conditions. The study revealed tangible depressive effects of leaves of all three tested leguminous agroforestry species on radicle elongation, root and shoot growth of bean and maize. We also observed that inhibitory effects were more pronounced on bean than on maize growth, while roots showed more sensitivity to allelochemicals than shoots. On that basis, roots should be considered the most suitable and reliable plant organs for allelopathic studies. From there, we conclude, in line with previous studies, that allelochemicals are not only species specific, but also organ specific. Their inhibitory effect is also controlled by their concentrations as the highest concentrations of Senna siamea L. and Gliricidia sepium (Jacq.) Walp showed highest negative effects on tested plant growth parameters. Interestingly, it could also be drawn from our study that Calliandra calothyrsus Meisn at both leaves application rates and to some extent Gliricidia sepium (Jacq.) Walp at lower rates showed stimulatory (positive) effects on maize root growth as compared to the control treatments. In the end, the allelopathic effect on bean and maize early growth parameters followed the order: Gliricidia sepium $>$ Senna siamea = Calliandra calothyrsus. This study outlines the potential detrimental effect of agroforestry species foliar biomass on associated plant growth when directly applied to soil. As an alternative, we recommand to farmers the co-composting approach with low quality crop harvest residues (e.g. maize stover, wheat straw), in which the leguminous leaves play a stimulatory effect on the overall decomposition, allelochemicals dissipation and plant nutrient release.

\section{AKNOWLEDGEMENT}

The authors wish to acknowledge the VLIR-UOS for the financial support given to the second author for his stay at VrijeUniversiteitBrussel (VUB) during which he accessed to the softwares and recent documentation which have been used in this paper preparation.

\section{REFERENCES}

1. Boullard, B., Guerre et paix dans le monde végétal. 1990, Paris, France: Aubin Imprimeur, 336 p.

2. Kohli, R., D. Batish, and H. Singh, Allelopathy and its implications in agroecosystems. Journal of Crop Production, 1997. 1(1): p. 169-202. 
3. Aguilera, N., et al., Effects and identification of chemical compounds released from the invasive Acacia dealbata Link. Chemistry and Ecology, 2015. 31(6): p. 479-493.

4. Ain, M.B.N., Y. Nornasuha, and B.S. Ismail, Allelopathic Assessment of Selected Common Weeds in Malaysia. 2016 Ukm Fst Postgraduate Colloquium, 2016. 1784.

5. Arroyo, A.I., et al., Evidence for chemical interference effect of an allelopathic plant on neighboring plant species: A field study. Plos One, 2018. 13(2).

6. Aslani, F., et al., Allelopathic effect of methanol extracts from Tinospora tuberculata on selected crops and rice weeds. Acta Agriculturae Scandinavica Section B-Soil and Plant Science, 2014. 64(2): p. 165-177.

7. Benchaa, S., M. Hazzit, and H. Abdelkrim, Allelopathic Effect of Eucalyptus citriodora Essential Oil and Its Potential Use as Bioherbicide. Chemistry \& Biodiversity, 2018. 15(8).

8. $\quad$ Bouhaouel, I., et al., Identification of Barley (Hordeum vulgare L. subsp. vulgare) Root Exudates Allelochemicals, Their Autoallelopathic Activity and Against Bromus diandrus Roth. Germination. Agronomy-Basel, 2019. 9(7).

9. $\quad$ Rice, E.L., Allelopathy. 2012: Academic press.

10. Kugedera, A. and L. Kokerai, Agroforestry Species Have Negative Allelopathic Effect on Food and Fodder Crops. 2019.

11. Zuo, S.P., et al., Allelopathy appraisal of worm metabolites in the synergistic effect between Limnodrilus hoffmeisteri and Potamogeton malaianus on algal suppression. Ecotoxicology and Environmental Safety, 2019. 182.

12. Zhu, W., et al., Effects of phytotoxic extracts from peach root bark and benzoic acid on peach seedlings growth, photosynthesis, antioxidance and ultrastructure properties. Scientia Horticulturae, 2017. 215: p. $49-58$.

13. Wang, X.J., et al., Allelopathic effects account for the inhibitory effect of field-pea (Pisum sativum L.) shoots on wheat growth in dense clay subsoils. Biology and Fertility of Soils, 2019. 55(7): p. 649-659.

14. Tchiechoua, Y.H., et al., Effect of indigenous and introduced arbuscular mycorrhizal fungi on growth and phytochemical content of vegetatively propagated Prunus africana (Hook. f.) Kalkman provenances. Plants, 2020. 9(1): p. 37.

15. Liu, J., et al., Allelopathic Effects, Physiological Responses and Phenolic Compounds in Litter Extracts of Juniperus rigidaSieb. et Zucc. Chemistry \& Biodiversity, 2017. 14(8).

16. Reigosa, M., et al., Comparison of physiological effects of allelochemicals and commercial herbicides. Allelopathy Journal, 2001. 8(2): p. 211-220.

17. Chaverri, C. and J. Cicció, Leaf and flower essential oil compositions of Gliricidia sepium (Fabaceae) from Costa Rica. Am. J. Essent. Oil Nat. Prod, 2015. 2(3): p. 18-23.

18. Cruz, M.G.M. and K.M.R. Cui-Lim, Phytochemical screening of the ethanol extract of (Jacq.) Steud Gliricidia sepium (Kakawate). Asian J. Phar. Pharm, 2016. 2(6): p. 150-153.

19. Abdulaziz, A.A., et al., Qualitative evaluation of the antimicrobial, antioxidant,and medically important phytochemical constituents of the ethanolic extracts of the leaves of Gliricidia sepium (Jacq.) Walp. Pharmacophore, 2019. 10(4).

20. Ang, A.M.G., et al., Antioxidant and Cytotoxic Activity of the Leaf Ethanolic Extracts of Tithonia diversofilia and Gliricidia sepium from Bukidnon, Philippines. Asian Journal of Biological and Life Sciences, 2019. 8(1): p. 9.

21. Cherian, T. and M. Thambi, Phytochemical investigation of the leaves of Gliricidia sepium and its antimicrobial properties. 2019.

22. Abdulrasheed, M., I.H. Isiaka, and I.A. Siddan, Determining the phytochemical constituents and the antimicrobial activity of ethanolic extract of Acassia Leaf (Senna Siamea) on some Enterobacteriaceae. IOSR J Pharm, 2015. 5: p. 1822 .

23. Mohammed, A., S. Mada, and H. Yakasai, Sub-chronic study of aqueous stem bark extract of Senna siamea in rats. Asian J. Biol. Sci, 2012. 5(6): p. 314-321.

24. Dahiru, D., A. Malgwi, and H. Sambo, Growth Inhibitory Effect of Senna siamea leaf extracts on selected microorganisms. American Journal of Medicine and Medical Sciences, 2013. 3(5): p. 103-107. 
25. Hassan, I.A., et al., Phytochemical studies and thin layer chromatography of leaves and flower extracts of Senna siamea lam for possible biomedical applications. Journal of Pharmacognosy and Phytotherapy, 2015. 7(3): p. 18-26.

26. Smith, Y.A., Determination of chemical composition of Senna-siamea (Cassia Leaves). Pakistan Journal of Nutrition, 2009. 8(2): p. 119-121.

27. Leonard, O.P., et al., Phytochemical characterization and cytotoxicity of Carissa edulis, Azadirachta indica, Cassia siamea and Harrisonia abyssinica from Masumbi Village, Siaya County-Kenya. J Sci Res Rep, 2016. 10: p. 1-10.

28. Bukar, A., M. Mukhtar, and A. Hassan, Phytochemical screening and antibacterial activity of leaf extracts of Senna siamea (Lam) on Pseudomonas aeruginosa. Bayero Journal of Pure and Applied Sciences, 2009. 2(1): p. $139-142$.

29. Kamagaté, M., et al., Ethnobotany, phytochemistry, pharmacology and toxicology profiles of Cassia siamea Lam. J. Phytopharmacol, 2014. 3(1): p. 57-76.

30. Christiana, K.A., et al., Phytochemical screening, proximate and elemental analyses of senna siamea (Lam.) leaves from Kashere metropolis of Gombe State, Nigeria. 2018.

31. Nas, F., T. Oyeyi, and M. Ali, Antibacterial Efficacy and Phytochemical Screening of Senna siamea Leaves Extracts on Some Pathogenic Bacteria. J. Microbiol Exp, 2018. 6(3): p. 159-163.

32. Kwada, A.D. and I. Tella, Determination of infochemicals and the phytochemical screening of the foliage and stem-bark of Senna siamea (lam.) in Yola, Adamawa State. Journal of Medicinal Plants Research, 2009. 3(9): p. 630-640.

33. Kumar, D., A. Jain, and A. Verma, Phytochemical and pharmacological investigation of Cassia siamea Lamk: An insight. The Natural Products Journal, 2017. 7(4): p. 255-266.

34. Rakhmani, S., et al., Composition of condensed tannins from Calliandra calothyrsus and correlation with in sacco digestibility. Animal Feed Science and Technology, 2005. 121(1-2): p. 109-124.

35. Setyawati, I., N. Wijayanti, and N. Wiratmini. Phytochemical content, extract standardization and antioxidant activity of Calliandra calothyrsus Meissn leaf, a potential phytoestrogen source. in IOP Conference Series: Earth and Environmental Science. 2019. IOP Publishing.

36. Asaduzzaman, M., et al., Metabolomics differentiation of canola genotypes: toward an understanding of canola allelochemicals. Frontiers in plant science, 2015. 5: p. 765.

37. Asaduzzaman, M., et al., Metabolomics differentiation of canola genotypes: toward an understanding of canola allelochemicals. Frontiers in Plant Science, 2015. 5.

38. Levitt, J., Introduction to plant physiology, The CV Mosby Company, St. 1974, Louis.

39. Weston, L., Utilization of allelopathy for weed management in agrosystems. 1997.

40. Oyun, M., Allelopathic potentialities of Gliricidia sepium and Acacia auriculiformis on the germination and seedling vigour of maize (Zea mays L.). American Journal of Agricultural and Biological Science, 2006. 1(3): p. 44-47.

41. Tian, G. and B. Kang, Evaluation of phytotoxic effects ofGliricidia sepium (Jacq.) Walp prunings on maize and cowpea seedlings. Agroforestry systems, 1994. 26(3): p. 249-254.

42. Chira, K., Structures moléculaire et perception tannique des raisins et des vins (Cabernet-Sauvignon, Merlot) du Bordelais. 2009, Bordeaux 2.

43. Kaboneka, S., et al., Carbon Mineralization Kinetics from Legume Residues Applied to a High Altitude Acidic Soil. Carbon, 2019.

44. Borchard, N., et al., Screening potential bioenergy production of tree species in degraded and marginal land in the tropics. Forests, 2018. 9(10): p. 594.

45. Danso, A. and P. Morgan, Alley cropping maize (Zea mays var. Jeka) with cassia (Cassia siamea) in The Gambia: crop production and soil fertility. Agroforestry systems, 1993. 21(2): p. 133-146.

46. Nelson, D. and L.E. Sommers, Total carbon, organic carbon, and organic matter 1. Methods of soil analysis. Part 2. Chemical and microbiological properties, 1982(methodsofsoilan2): p. 539-579. 
47. Bremner, J.M. and C. Mulvaney, Nitrogen-total 1. Methods of soil analysis. Part 2. Chemical and microbiological properties, 1982(methodsofsoilan2): p. 595-624.

48. Mehlich, A., Mehlich 3 soil test extractant: A modification of Mehlich 2 extractant. Communications in soil science and plant analysis, 1984. 15(12): p. 1409-1416.

49. Baize, D., Soil science analyses: a guide to current use. 1993: John Wiley \& Sons Ltd.

50. Anwar, C., Study of the allelopathic effect of Eucalyptus spp. On growth of maize seedlings. Bull. Penelitian Hutan, 1991. 547: p. 9-17.

51. Bhardwaj, S., Effect of leaf leachate of Robinia pseudoacacia on seed germination and growth of some agricultural crops. Indian Journal of Forestry, 1993. 16(3): p. 285-286.

52. Melkania, N., Influence of leaf leachates of certain woody species on agricultural crops. Indian Journal of Ecology, 1984.

53. Adeorike, V., M. Ogburia, and P. Anegbeh, Evaluation of the Allelopathic Influence of Selected Multi-purpose Tree Species on Maize (Zea mays) under a Simu. Tropicultura, 2001. 19(4): p. 191-193.

54. Quddus, M.S., S.M. Bellairs, and P.A. Wurm, Acacia holosericea (Fabaceae) litter has allelopathic and physical effects on mission grass (Cenchrus pedicellatus and C. polystachios)(Poaceae) seedling establishment. Australian Journal of Botany, 2014. 62(3): p. 189-195.

55. Abugre, S., et al., Allelopathic effects of ten tree species on germination and growth of four traditional food crops in Ghana. Journal of Agricultural Technology, 2011. 7(3): p. 825-834.

56. El Ayeb, A., H.B. JANNET, and F.H. SKHIRI, Effects of Acacia cyanophylla Lindl. extracts on seed germination and seedling growth of four crop and weed plants. Turkish Journal of Biology, 2013. 37(3): p. 305-314.

57. Ayeni, M.J., Effect of aqueous extracts of the leaves of Senna siamea Lam. and Pinus carribaea (Jacq.) ex. Walp. on the germination and seedling growth of Euphorbia heterophylla L. World Scientific News, 2017. 87: p. 12-23.

58. MUTAQIEN, Z. Presumption of allelopathic compound (s) released in the leaf litter decomposition process of invasive plants: Calliandra calothyrsus and Cinchona pubescens. in Prosiding Seminar Nasional Masyarakat Biodiversitas Indonesia. 2017.

59. Nasir, M., S. Ahmed, and M. Hassan, Effect of Cassia siamea and Gliricidia sepium leaf in controlling weed of transplanted aman rice on the Madhupur tract of Bangladesh. International Journal of Agronomy and Agricultural Research, 2016. 8(1): p. 64-70. 